\title{
Pepatah masyarakat Sunda sebagai inspirasi desain: Studi kasus pada perancangan body shell mobil pedesaan
}

\author{
Andry Masri, ${ }^{1 *}$ Fred Saritua Rudianto, ${ }^{2}$ Amirul Nefo ${ }^{3}$ \\ ${ }^{123}$ Program Studi Desain Produk, Institut Teknologi Nasional, Bandung, Indonesia
}

\begin{abstract}
The vehicle as an artifact is an object related to humans through sense, so human behavior in using the product is related to the values that will underlie the interpretation that is carried out as behavior directed by attitudes, and the attitude itself is formed by the values held. This raises the consequence that the design of a product to use must consider the values adopted or that apply to the community, which in turn will underlie the design concept of the product itself. This research tries to offer an approach to get a value that applies to a particular society by interpreting the qualities that exist in the proverb or proverb that is used by the people who will receive the product so that it is expected to obtain a visual basic concept that is in accordance with the values that apply to the community. The method used is a qualitative research method with an analytical approach to observing the response to a given visual stimulus. Starting with the collection of sayings that apply to the prospective user community, formulated values adopted by the community are represented based on adjectives. The results of the formulation of values are then translated into visual concepts which are then tested on the community through questionnaires in the form of product image assessment. It was concluded that the community has the ability to capture the design value offered by a product so that a visual concept can be formulated for a design.
\end{abstract}

Key words: appropriateness of product values, values on the proverb, visual concept

\begin{abstract}
Abstrak
Kendaraan sebagai sebuah artefak adalah objek yang berhubungan dengan manusia melalui alat indra, sehingga perilaku manusia dalam menggunakan produk tersebut terkait dengan nilai yang akan mendasari penafsiran yang dilakukan sebagai perilaku yang diarahkan oleh sikap, dan sikap itu sendiri yang dibentuk oleh nilai yang dianut. Hal ini memunculkan konsekuensi bahwa perancangan sebuah produk pakai harus mempertimbangkan nilai yang dianut atau yang berlaku pada masyarakat tersebut, yang selanjutnya akan mendasari konsep perancangan dari produk itu sendiri. Penelitian ini mencoba menawarkan satu pendekatan untuk mendapatkan nilai yang berlaku pada masyarakat tertentu dengan menafsirkan sifat-sifat yang ada pada pepatah atau peribahasa yang digunakan oleh masyarakat yang akan menerima produk sehingga diharapkan diperoleh konsep dasar visual yang sesuai dengan nilai yang berlaku pada masyarakat tersebut. Metoda yang digunakan adalah metoda penelitian kualitatif dengan pendekatan analisis terhadap observasi respon terhadap stimulus visual yang diberikan. Diawali dengan pengumpulan pepatah yang berlaku pada masyarakat calon pengguna, dirumuskan nilai-nilai yang dianut oleh masyarakat tersebut yang direpresentasikan berdasarkan kata sifat. Hasil rumusan nilai kemudian diterjemahkan pada konsep-konsep visual yang kemudian diujikan kepada masyarakat melalui kuisioner berupa penilaian citra produk. Diperoleh kesimpulan bahwa masyarakat memiliki kemampuan untuk menangkap nilai desain yang ditawarkan oleh sebuah produk sehingga dapat dirumuskan sebuah konsep visual untuk sebuah rancangan.
\end{abstract}

Kata kunci: kesesuaian nilai produk, nilai pada pepatah, konsep visual

\section{Pendahuluan}

Konsumen sebagai calon pengguna dari sebuah rancangan produk akan berhubungan dengan produk secara visual, sebelum pengguna menyentuh produk.
Hubungan secara visual tidak hanya terjadi pada awal penggunaan saja, pada saat pengguna mengoperasikan, hingga meletakkannya pada sebuah tempat atau ruangan, ia akan berhubungan secara visual, oleh karena itu tampilan visual produk

* Corresponding author e-mail : andrymasri@gmail.com. 
memainkan peran penting dalam menentukan respons konsumen. Secara visual, penilaian menarik atau tidaknya sebuah produk tidak hanya mencakup pertimbangan apakah produk terlihat bagus, tetapi juga menampilkan fungsi dari produk, dan menyampaikan sesuatu mengenai orang yang akan memiliki produk tersebut. Desain yang baik akan menarik konsumen pada produk, berkomunikasi dengan mereka, dan memberi nilai tambah pada produk dengan meningkatkan kualitas pengalaman penggunaan yang terkait dengannya (Bloch, 1995).

Kebutuhan dari pengguna untuk sebuah produk seringkali mengacu pada hierarki kebutuhan dari Maslow, yang menunjukkan bahwa ketika masalah kegunaan, keamanan dan kenyamanan telah terpenuhi, penekanan dapat beralih ke atribut dekoratif, emosional dan simbolis dari desain. (Crilly, Moultrie, \& Clarkson, 2004). Hal ini dengan kata lain menunjukkan bahwa tuntutan terhadap sebuah produk, tidak lagi sebuah pemenuhan kebutuhan saja, melainkan pemenuhan keinginan atau hasrat, menurut Hartmut Esslinger, desain yang memiliki tampilan yang menarik dan fungsionalpun tidak akan memenuhi keinginan atau hasrat seseorang kecuali hal tersebut dapat menyentuh faktor emosi. Desain yang bagus tidak hanya cantik atau modis, tapi harus identik dan konsisten dalam menciptakan kepemilikan sosial. (Hout, 2006).

Respons kognitif mengacu pada penilaian yang dibuat oleh pengguna atau konsumen tentang produk berdasarkan informasi yang ditangkap oleh indera. Penilaian ini mencakup evaluasi kualitas yang dirasakan produk, yang didasarkan beberapa literatur dapat dikelompokkan menjadi tiga kategori yaitu: impresi estetik, interpretasi semantik dan asosiasi simbolis. (Crilly, Moultrie, \& Clarkson, 2004)

Kata afeksi biasanya digunakan sebagai istilah umum untuk menggambarkan emosi, mood dan perasaan ini yang digambarkan sebagai bagian dari "respons psikologis konsumen terhadap konten semiotik produk". Konsumen mengevaluasi produk dengan mempertimbangkan berbagai hal yang bersifat fisik berupa kebutuhan, hingga kehidupan yang diharapkan. Kombinasi dari hal tersebut memunculkan emosi yang berpotensi dapat mempengaruhi keputusan konsumen. Respon emosional dapat mendorong seseorang untuk memilih artefak tertentu dari beberapa pilihan yang tersedia. Sebagai konsekuensinya, desainer ditantang untuk memanipulasi dampak emosional dari rancangan mereka, atau, 'merancang emosi' (Desmet, 2003). Selanjutnya, menurut Desmet (2003), untuk merancang emosi dibutuhkan pemahaman mendalam tentang makna emosional yang beragam yang dapat ditafsirkan oleh pengguna yang dimaksud, perancangan emosi bukan melulu persoalan styling saja.

Dengan demikian, untuk dapat menyentuh emosi dari pengguna, maka perancangan sebuah produk memerlukan perspektif semiotik yang berfokus pada melihat produk sebagai tanda yang mampu merepresentasikan makna. Salah satu dari atribut makna dapat merupakan sebuah kata sifat, yang menurut vihma, bagi seorang Desainer, salah satu tugasnya adalah mengkomunikasikan atribut sifat melalui media produk. (Vihma, 1995).

Didasarkan pada konsep triadik Pierce yang berdasarkan intepretant terdapat jenis tanda yang disebut dengan rheme, decisign, dan argument (Zoest, 1993). Pada konsep triadik tersebut, terdapat tanda yang sudah memiliki konvensi untuk ditafsirkan dengan makna tertentu (argument), kemudian terdapat tanda yang kejelasan penafsirannya sudah dapat dipastikan (decisign), dan terakhir adalah tanda yang masih memiliki penafsiran yang ambigu (rheme). Sebuah desain, jika dianggap sebagai sebuah tanda, maka akan mengkomunikasikan sifat yang sesuai dengan makna yang diharapkan hadir oleh masyarakat pengguna, artinya konsep visual yang menjadi tanda harus merupakan argument, akan tetapi pada tugasnya yang lain, desain tidak dapat menghasilkan sesuatu yang tidak memiliki nilai kebaruan. Oleh karenanya sebuah desain dituntut untuk memanfaatkan tanda yang telah menjadi argument, dan menghindarkan diri dari tanda yang bersifat rheme, akan tetapi tetap harus menawarkan sebuah kehadiran tanda baru.

Bentuk komunikasi yang paling konvensional adalah bahasa yang merupakan medium penting dalam semua interaksi manusia yang mengungkapkan pengalaman baik itu secara individu mapun secara kolektif dalam memandang dunia sekitarnya. (Akihary, 2011). Melalui bahasa, manusia berkomunikasi, menyampaikan pesan, menerima pesan, dan menafsirkannya, ia merupakan alat utama pemikiran dan persepsi, inti dari siapa seseorang sebagai individu. Bahasa terus berubah, terkadang menjadi jenis cara berbicara yang sama sekali baru, yang menyebabkan perbedaan halus dalam bagaimana seseorang menampilkan dirinya kepada orang lain. (Jourdan \& Tuite, 2006)

Dalam konteks sosial, bahasa sebagai medium komunikasi merupakan gambaran budaya masyarakat penuturnya, memperlihatkan apa yang dianggap penting didalam kehidupan sosialnya, apa yang mempengaruhinya pada masa lampau, dan apa yang ideal diharapkan oleh masyarakat tersebut. Bahasa adalah cerminan budaya masyarakat penuturnya. 
Sebaliknya, budaya masyarakat penutur suatu bahasa dapat dibaca melalui bahasanya. (Oktavianus, 2013)

Nilai ideal dari konstruksi sosial sebuah masyarakat dapat terlihat pada pilihan kata, objek yang secara unik disampaikan pada sebuah idiom, peribahasa, atau pepatah pada sebuah lingkungan sosial. Setiap masyarakat memiliki apa yang disebut sebagai peribahasa yang merupakan susunan kata yang khas, yang mampu membedakan identitas antara satu masyarakat dengan masyarakat lain. Setiap pembentukan kata-kata bahkan kalimat dalam suatu bahasa, seperti sebuah peribahasa, memperlihatkan sifat atau ciri pikiran dalam kebudayaan masyarakat tersebut. (Sibarani, 2004 )

Memahami nilai yang berlaku pada sebuah masyarakat, bahasa merupakan medium komunikasi yang digunakan didalam interaksi sosial. Berbeda dengan teori mengenai komunikasi, di dalam teori semiotika hal yang menjadi perhatian adalah konstruksi makna apa yang terbentuk pada manusia ketika seseorang harus menafsirkan sebuah pesan, bukan pada efektifitas sampainya sebuah pesan atau kesamaan dengan maksud dari pengirim. (Fiske, 1990). Hal ini menunjukkan bahwa pada semiotika, konstruksi sebuah makna seseorang akan berbeda satu sama lain, bergantung pada kode yang melatarinya antara lain adalah nilai sosial. Dari salah satu cirinya, nilai sosial merupakan konstruksi abstrak dalam pikiran orang yang tercipta melalui interaksi sosial (Santosa, 2009)

Desain adalah bidang kreasi yang menawarkan solusi dalam bentuk visual, sebagai tanda setiap unsur visual akan disusun berdasarkan strategi tertentu agar diperoleh susunan atau komposisi visual yang dapat menjadi sebuah stimulus bagi proses penafsiran (Masri, 2010). Dengan demikian perancangan sebuah produk harus mempertimbangkan nilai yang dianut oleh masyarakat di mana produk tersebut akan digunakan, karena pada dasarnya produk adalah kumpulan tanda yang akan ditafsirkan oleh masyarakat sebagai pengguna produk yang dirancang. Upaya mencari nilai yang dianut tersebut adalah memungkinkan ditelusuri melalui aspek bahasa seperti kehadiran pepatah atau peribahasa (proverba) yang digunakan pada lingkungan masyarakat tertentu.

\section{Bahan dan metode}

Dalam konteks budaya, masyarakat Sunda memiliki nilai filosofis yang tertuang salah satunya dalam peribahasa Sunda , "silih asah, silih asih dan silih asuh". Ketiga terminologi ini dianggap merupakan ruh dalam pengembangan kehidupan masyarakat Sunda. kehidupan dalam masyarakat Sunda senantiasa mengedepankan nilai kebersamaan, yakni maju bersama dalam intelektualitas (silih asah), kekuatan kasih sayang yang senantiasa diciptakan dalam segala bentuk hubungan individu satu sama lain (silih asih), dan sikap mengayomi satu sama lain sebagai bagian yang tak terpisahkan dalam menciptakan harmonisasi hidup (silih asuh) (Fauzi, 2017).

Yang menjadi menarik adalah pilihan kata asah yang menggunakan kata dari kegiatan memperuncing alat, mempertajam atau menghaluskan sesuatu, dilakukan secara berulang. Hal ini memperlihatkan bahwa masyarakat meyakini bahwa proses adalah lebih penting dibandingkan hasil, dan bukan merupakan sesuatu yang bersifat instan. Penggunaan kata "silih", yang memiliki arti "saling” menunjukkan sifat non individual pada masyarakat Sunda. Beberapa tafsiran dari pepatah atau peribahasa yang ada pada masyarakat Sunda dapat dilihat dibawah ini;

a. Ulah waka make sorban lamun make panas baran (jangan dulu pakai sorban kalau masih memiliki rasa iri). Ulah waka make jubah mun hirup can balabah. (jangan dulu pakai jubah kalau hidup belum dermawan).

Tafsiran: Tampilan adalah sesuatu yang penting untuk dipertimbangkan secara hati-hati, menunjukkan kondisi kesanggupan yang cenderung untuk lebih rendah dari sesungguhnya (sikap hati hati) - pada sudut pandang lain, dapat dipahami bahwa penampilan adalah sesuatu yang dipakai sebagai media komunikasi. Sejak dahulu sesepuh Sunda menegaskan jika tingkat kemuliaan seseorang tidak dipandang dari segi penampilan. Pesannya adalah jangan karena sudah memakai atribut sesuatu, lantas menjadi orang yang jemawa.

Penggunaan sorban atau jubah menunjukkan bahwa terdapat argument untuk tampilan visual tertentu.

Tidak sombong - rendah hati. Terdapat panduan hidup bersosial, kedermawanan orang Sunda harus didahulukan ketimbang gaya hidup. Jubah dalam budaya Sunda disimbolkan sebagai makna kekuatan dan kejayaan.

b. Kabengkeut ku nu diiket, kapélét ku nu dikamprét. (terikat oleh yang memakai ikat kepala, kepelet oleh yang memakai kampret), Kajaring ku nu disamping, nyariosna meuni nyaring (terjaring oleh yang menggunakan kain sarung dan bicaranya sangat nyaring).

Tafsiran: Ikat pada kalimat ini dimaknai merupakan ikat khas yang dipakai oleh seorang 
pemuka agama. Penggunaan atribut tersebut menuntut pemikiran yang harus lebih hebat dan ahlak juga harus lebih baik. Pada masa lalu, sebenarnya iket dipakai dengan aturan-aturan yang baku, terkesan rumit dan susah dalam pemakaiannya. Hal tersebut memberikan makna bahwa setiap orang yang memakainya harus bersusah payah terlebih dahulu sebelum mendapatkan bentuk iket yang bagus. Susah payah dalam memakai ikat diyakini agar ia juga siap untuk bersusah payah dalam menghadapi berbagai persoalan kehidupan. Itulah kenapa komunitas adat di tatar Sunda tidak memberikan iket praktis kepada anak-anaknya.

Kain yang digunakan berbentuk segi empat yang konon bertujuan agar seseorang dapat belajar dengan susah payah memakainya. Sehingga, dalam kehidupan sehari-hari generasi muda diharapkan mau bersusah payah dalam menghadapi setiap cobaan dalam kehidupan. lket sendiri itu artinya ikat, atau mengikat, sehingga dapat mengikat semua potensi diri tubuh, jiwa, spirit. Artinya bahwa entitas potensi orang Sunda itu "diiket" atau diikat dalam satu kesatuan, sehingga menjadi suatu pribadi atau personality kaSundaan, yang silih asih, asah dan asuh (Djava, 2017) (kebersamaan lebih penting daripada individualitas). Kehati-hatian dalam berbicara memperlihatkan bahwa pemikiran sebelum mengungkapkan menjadi sangat penting.

c. Manusia Sunda adalah manusia Sunda yang 'ngindung ka waktu ngabapa ka jaman,'

Tafsiran: Harus bisa mengikuti perkembangan kekinian. Tidak hanya terpaku dan terpukau pada kejayaan masa lalu, tapi visioner sekarang dan masa depan

d. Ngeduk cikur kedah mitutur, nyokel jahé kedah micarék (Nggak boleh korupsi, maling, nilep, dan sebagainya kalau mau ngambil sesuatu harus seijin yang punya) (faquha, 2016).

Tafsiran : Toleransi terhadap lingkungan sangat tinggi (menjadi sangat penting). Kejujuran adalah nilai yang dianut. Walaupun tidak besar, terdapat nilai kepemilikan disamping kebersamaan

e. Sacangreud pageuh sagolek pangkék (menepati janji \& konsisten) Kudu hadé gogog hadé tagog (harus konsisten dengan perilakunya)

Tafsiran: Konsistensi adalah sikap yang diharapkan dari masyarakat Jawa Barat.

f. Ulah lunca linci luncat mulang udar tina tali gadang, ulah lali tina purwadaksina. Nyaur kudu diukur nyabda kudu diunggang (berbicara harus tepat, jelas, bermakna, dan tidak asbun).
Tafsiran: dekorasi bukan hal utama, kejelasan menjadi lebih utama, walaupun pada sisi lain masih menghargai kesepakatan (konvensi) dalam bentuk simbol

g. Kudu silih asih, silih asah jeung silih asuh (harus saling mencintai, memberi nasihat dan mengayomi).

Tafsiran: Nilai kebersamaan adalah hal yang utama bagi masyarakat Jawa Barat

h. Bengkung ngariung bongok ngaronyok (kompak dalam hal menghadapi kesulitan/ masalah harus di selesaikan bersama).

Tafsiran: kebersamaan

i. Bobot pangayon timbang taraju (semua yang dilakukan harus penuh pertimbangan )

Tafsiran: Kehati-hatian

j. $\quad$ Lain palid $k u$ cikiih lain datang $k u$ cileuncang (harus ada tujuan yang jelas sebelum melangkah ) Tafsiran: kejelasan

k. Tarajé nangeuh dulang tinandé (setiap tugas harus dilaksanakan dengan baik dan benar).

Tafsiran: kejelasan dengan adanya kesesuaian terhadap tugas atau peran

l. Ulah pagiri- giri calik, pagirang-girang tampian (jangan berebut kekuasaan, sirik pidik, jail kaniaya).

Tafsiran: Tidak kompetitif (nilai agresivitas cukup rendah)

m. Ulah ngukur baju sasereg awak (jangan hanya melihat dari kaca mata sendiri).

Tafsiran: proporsional

n. Ulah nyaliksik ku buuk leutik (jangan memperalat yang lemah, membesarkan perkara)

Tafsiran: sederhana, tidak rumit

o. Ulah kuméok méméh dipacok (ksatria, jangan mundur sebelum berupaya keras).

Tafsiran: satria

p. Mun teu ngoprék moal nyapék, mun teu ngakal moal ngakeul, mun teu ngarah moal ngarih (segalanya harus pakai akal dan harus terus diulik, diteliti, kalau sudah diteliti dan dijadikan sesuatu yang bermanfaat untuk kehidupan).

Tafsiran: intelektual

q. Neangan luang ti papada urang (belajar mencari wawasan pengetahuan dari pengalaman orang lain).

Tafsiran: intelektual

r. $\quad \mathrm{Nu}$ lain kudu dilainkeun nu enya kudu dienyakeun (speak the truth nothing but the truth).

Tafsiran: jelas dan lugas

s. Kudu paheuyeuk- heuyeuk leungeun paantayantay panangan (saling membantu)

Tafsiran: kebersamaan 
t. Ka cai jadi saleuwi, ka darat jadi saleba (kompak, harmonis dalam team work )

Tafsiran: kebersamaan

Berdasarkan kajian pada nilai yang ada pada peribahasa masyarakat Sunda tersebut dapat diperoleh nilai sebagai berikut :

a. Bahwa tampilan adalah sesuatu yang penting untuk dipertimbangkan secara hati-hati

b. Berlaku simbol simbol yang dikonvensikan oleh masyarakat Jawa Barat seperti ikat pada kalimat ini dimaknai merupakan ikat khas yang dipakai oleh seorang pemuka agama.

c. Dapat dipahami bahwa penampilan adalah sesuatu yang dipakai sebagai media komunikasi.

d. Dekorasi bukan hal utama, kejelasan menjadi lebih utama, walaupun pada sisi lain masih menghargai kesepakatan (konvensi) dalam bentuk simbol

e. Harus bisa mengikuti perkembangan kekinian.

f. Intelektual

g. Kebersamaan

h. Kehati-hatian.

i. Kejelasan dan kelugasan

j. Kejujuran

k. Kemewahan pada atribut diletakkan secara hatihati, karena berlaku pemahaman simbolik.

l. kesederhana, tidak rumit

m. Konsistensi.

n. Ksatria

o. Persegi empat, yang disimbolkan dari Kain ditafsirkan sebagai kesempurnaan.

p. proporsional

q. Terdapat sifat Tidak sombong - rendah hati. Terdapat panduan hidup bersosial, kedermawanan orang Sunda harus didahulukan ketimbang gaya hidup. Jubah dalam budaya Sunda disimbolkan sebagai makna kekuatan dan kejayaan.

r. Tidak kompetitif (nilai agresivitas cukup rendah)

s. Toleransi terhadap lingkungan sangat tinggi (menjadi sangat penting).

Nilai nilai tersebut kemudian dicoba diabstraksi menjadi nilai berikut: (1) Bahwa tampilan adalah sesuatu yang penting untuk dipertimbangkan secara hati-hati, karena berlaku simbol simbol dan digunakan sebagai media komunikasi; (2) Kejelasan (intelektualitas) lebih penting dari dekorasi, dan mengikuti perkembangan kekinian. Lebih mengarah pada sifat yang sederhana (tidak agresif), dan toleransi terhadap lingkungan sangat tinggi (kebersatuan dan keselarasan) yang akan memunculkan kesan ramah secara visual; (3) Kebersamaan dibanding individualitas;
Proporsional (berlaku pengalaman terhadap persepsi yang sudah ada dalam memori).

\section{Hasil dan pembahasan}

Didasarkan pada nilai yang berlaku pada masyarakat tersebut, tafsiran harus dipertentangkan dengan nilai fungsional dari kendaraan pedesaan yang dibuat, yaitu bahwa kendaraan adalah produk yang memiliki nilai: (1) Agresivitas tinggi; (2) Mengandalkan kekuatan; (3) Lincah; (4) Individual.

Dari sudut pandang objek tersebut, terlihat beberapa pertentangan terhadap nilai yang dianut oleh masyarakat. Sehingga diperlukan strategi untuk mendapatkan keseuaian terhadap bentuk ideal yang diharapkan dengan apa yang selama ini dianut sebagai perilaku keseharian.

Tabel 1. Kesimpulan nilai

\begin{tabular}{|l|l|l|}
\hline $\begin{array}{l}\text { Nilai yang dianut pada } \\
\text { subjek }\end{array}$ & Nilai dari kendaraan & Nilai Kompromi \\
\hline Ramah & Agresif & $\begin{array}{l}\text { Ramah tapi memiliki nilai } \\
\text { gesit, agresifitas harus hilang }\end{array}$ \\
\hline & Kuat & $\begin{array}{l}\text { Tetap memiliki nilai } \\
\text { kekuatan, akan tetapi tidak } \\
\text { agresif. }\end{array}$ \\
\hline & Lincah & Lincah \\
\hline Kebersamaan & Individual & Harmonis \\
\hline Proporsional & & \\
\hline
\end{tabular}

Sketsa penafsiran awal

Untuk penggalian konsep visual, dilakukan sketsa penafsiran awal dalam upaya mencari karaktersitik visual yang mampu merepresentasikan nilai tersebut. Beberapa gagasan awal dapat dilihat pada Gambar 1.

Gagasan 01 merupakan upaya pencarian dari nilai (1) Kejelasan dan kelugasan yang dikompromikan dengan karaktersitik fungsional dari kemampuan penjelajahan sebagai wakil dari karakteristik ksatria; (2) Kejujuran diupayakan melalui penjabaran perbedaan komponen; (3) Kemewahan pada atribut diletakkan secara hati-hati, dengan meminjam pemahaman simbolik dari kendaraan yang sudah pernah ada (jeep); (4) Kesederhanaan, tidak rumit diperoleh dari pemilihan garis yang dominan horisontal; (5) Konsistensi, diperoleh dengan peneguhan pada pilihan bentuk persegi empat; dan (6) Toleransi terhadap lingkungan sangat tinggi dilakukan melalui pertimbangan pemilihan tanpa atap.

Gagasan 02 merupakan upaya pencarian dengan meminjam makna daun sebagai sesuatu yang sangat akrab dengan masyatakat Jawa Barat. Pendekatan 
biodesign ini bertentangan dengan nilai persegi yang ada pada filosofi masyarakat Jawa Barat, akan tetapi dalam pemahaman sebagai makna kesempurnaan, hal ini dapat diabaikan.

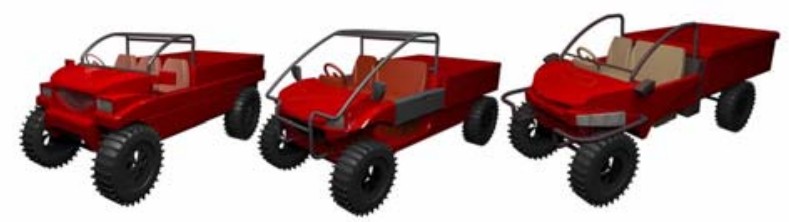

Gambar 1. Sketsa Gagasan 01, 02, dan 03 (kiri ke kanan)

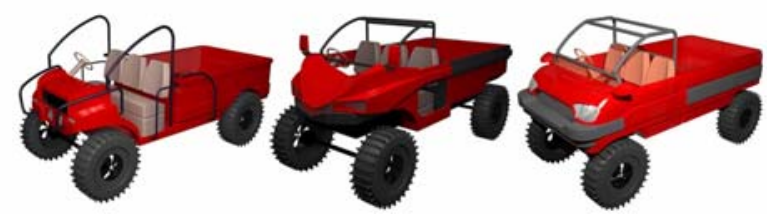

Gambar 2. Sketsa gagasan 04, 05, dan 06 (kiri ke kanan)

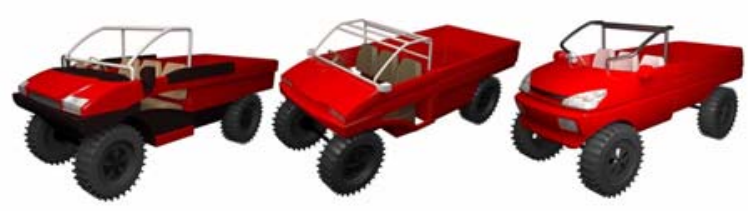

Gambar 3. Sketsa gagasan 07, 08, dan 09 (kiri ke kanan)

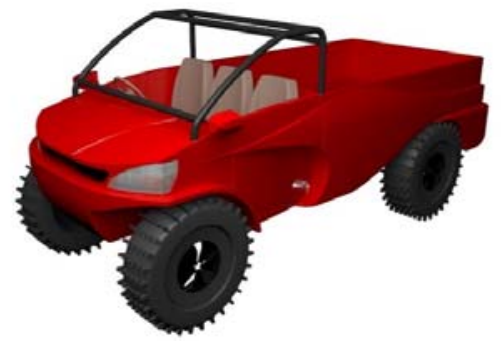

Gambar 4. Sketsa gagasan 10

Secara umum, nilai lain yang dapat diperoleh pada gagasan 02 dapat diuraikan sebagai berikut: (1) Kejelasan dan kelugasan yang dikompromikan dengan karaktersitik fungsional dari kemampuan penjelajahan sebagai wakil dari karakteristik ksatria; (2) Kejujuran diupayakan melalui penjabaran perbedaan komponen; (3) Kemewahan pada atribut diletakkan secara hati-hati, dengan meminjam pemahaman simbolik dari kendaraan yang sudah pernah ada (konsep visual desain kendaraan saat ini); (4) Kesederhanaan, tidak rumit diperoleh dari penyusunan garis organis yang diatur secara analogus;
(5) Konsistensi, diperoleh dengan peneguhan pada pilihan bentuk organis; dan (6) Toleransi terhadap lingkungan sangat tinggi dilakukan melalui pertimbangan pemilihan tanpa atap serta metafora dari daun. Pengembangan dari gagasan 02 dilakukan pada gagasan 03, yaitu melalui komposisi komplementer antara garis organis dan garis tegas.

Berbeda dengan gagasan sebelumnya, penekanan pada gagasan 04 adalah sebagai upaya pencarian pada nilai kelugasan dan kesederhaan. Gagasan 05 dititikberatkan pada sifat agresivitas yang menjawab tuntutan dari kondisi geografis pedesaan. Metafora dari daun tetap digunakan, akan tetapi nilai filosofi masyarakat diabaikan dengan penitik beratan pada nilai kekinian. Pendekatan untuk mendapatkan nilai kesederhanaan dan mengurangi agresivitas dilakukan pada gagasan 06. Melepaskan diri dari metafora daun, upaya kesederhanaan diambil dari unsur visual desain kendaraan yang dianggap akrab dengan masyarakat saat ini (Gambar 2).

Upaya untuk mengkompromikan nilai yang bertentangan pada gagasan 01, 02, dan 06 dicoba untuk dijawab pada gagasan 07. Upaya dekoratif sebagai implementasi dari kecenderungan masyarakat terhadap 'hiasan' dicoba diterapkan. Dengan tujuan yang sama pada gagasan 07, gagasan 08 mencoba melihat nilai yang dicapai tanpa melibatkan unsur dekoratif. Gagasan 09 adalah pengembangan nilai kesederhanaan dari gagasan 06, dengan menambah unsur agresivitas dan kelincahan (Gambar 3).

Berbeda dengan pendekatan pada gagasan sebelumnya, pada gagasan 10, dilakukan pendekatan berbasis inspirasi. Pada gagasan ini dicoba membuat rancangan didasarkan pada salah satu bentuk artefak yang dimiliki oleh masyarakat Jawa Barat, antara lain artefak kujang (Gambar 4).

\section{Uji Responden}

Rumusan dari penggalian konsep visual tersebut diatas, kemudian diujicobakan pada masyarakat melalui kuisioner yang dibagikan secara online, dan sebanyak 41 orang bersedia untuk mengisi. Pada kuisioner, responden diminta untuk memilih kata sifat sebagai representasi dari gagasan yang ditampilkan, kemudian responden akan memilih sifat dari rentang skala Likert 0 - 5. Responden diminta untuk memberi nilai berdasarkan sumbu bipolar dari sifat yang diberikan (Gambar 5), yaitu

a. Sifat kebersamaan sumbu individual - sangat bersama.

b. Sifat agresivitas sumbu tidak agresif - sangat agresif.

c. Sifat ketangguhan sumbu tidak tangguh - sangat tangguh. 
Andry Masri, Fred Saritua Rudianto, Amirul Nefo

Pepatah masyarakat Sunda sebagai inspirasi desain: Studi kasus pada perancangan body shell mobil pedesaan

d. Sifat keramahan sumbu tidak ramah - sangat ramah.

e. Sumbu kelincahan sumbu tidak lincah - sangat lincah.

f. Sumbu kelembutan sumbu tidak lembut - sangat lembut.

Dari penilaian yang diberikan oleh responden, dicari nilai rata-rata penilaian dari setiap sifat yang ditawarkan dari setiap sketsa gagasan. Hasil dari kuisioner dapat dilihat pada Gambar 6. Hasil survey menunjukkan bahwa sketsa gagasan 10 memiliki nilai tertinggi dari sifat kebersamaan dan ketangguhan, sedangkan sketsa gagasan 06 memiliki nilai tertinggi dengan sifat agresif dan kelincahan, serta sketsa 05 memiliki nilai tertinggi untuk sifat keramahan dan kelembutan.

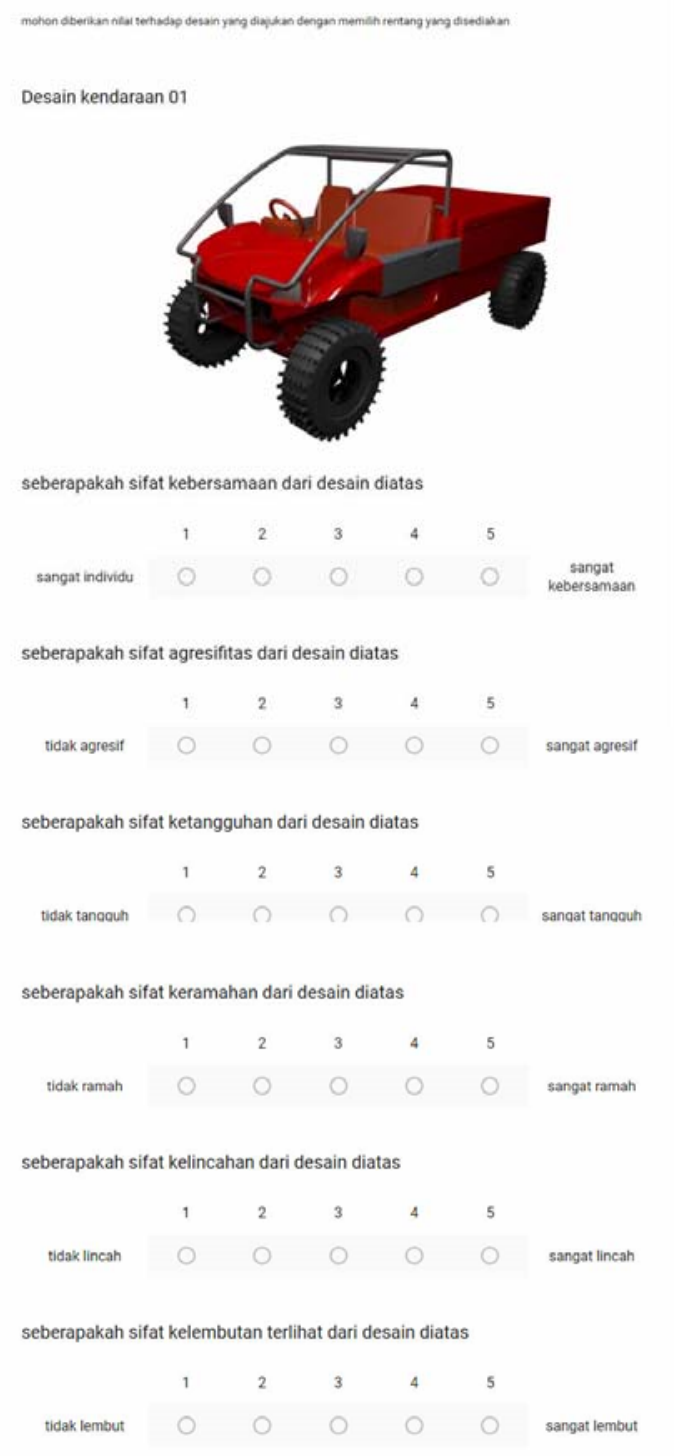

Gambar 5. Lembar kuisioner

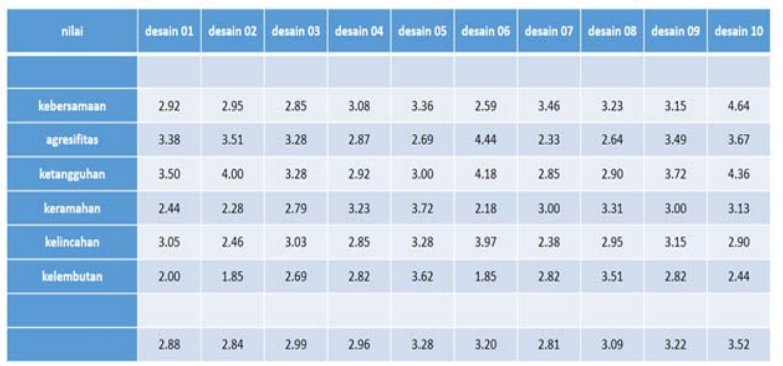

Gambar 6. Tabel resume kuisioner

\begin{tabular}{|c|c|c|c|c|c|}
\hline & desain 05 & desain 06 & desain 08 & desain 09 & desain 10 \\
\hline kebersamaan & 3.36 & 2.59 & 3.23 & 3.15 & 4.64 \\
\hline agresifitas & 2.69 & 4.44 & 2.64 & 3.49 & 3.67 \\
\hline Ketangsuhan & 3.00 & 4.18 & 2.90 & 3.72 & 4.36 \\
\hline keramahan & 3.72 & 2.18 & 3.31 & 3.00 & 3.13 \\
\hline kellincahan & 3.28 & 3.97 & 2.95 & 3.15 & 2.90 \\
\hline kelembutan & 3.62 & 1.85 & 3.51 & 2.82 & 2.44 \\
\hline & 3.28 & 3.20 & 3.09 & 3.22 & 3.52 \\
\hline
\end{tabular}

Gambar 7. Tabel resume nilai tertinggi

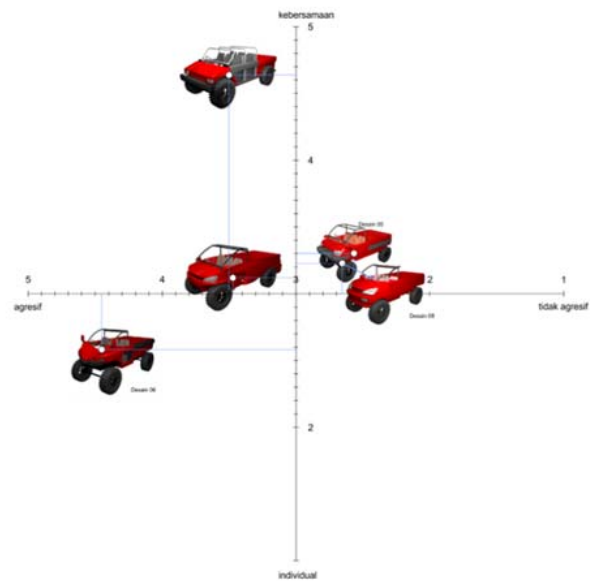

Gambar 8. Peta citra hasil survey berdasarkan sumbu kebersamaan agresivitas

Dari Gambar 7 yang memperlihatkan tabel resume nilai tertinggi, dapat terlihat bahwa sifat agresivitas diperoleh oleh sketsa desain 05 dan 06, dan secara keseluruhan, kedua desain memiliki nilai yang mirip. Desain 06 memiliki nilai kelincahan, agresivitas, dan ketangguhan yang cukup tinggi yang justru bertentangan dengan nilai yang berlaku pada masyarakat Sunda. Akumulasi nilai tertinggi memang ada pada desain 10, akan tetapi nilai agresivitas dan ketangguhan sangat besar, sehingga tidak cocok dengan nilai yang dianut oleh masyarakat. 


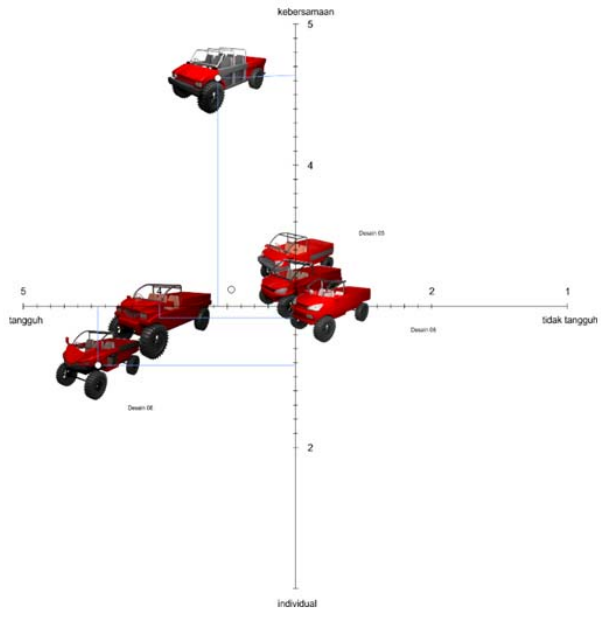

Gambar 9. Peta citra hasil survey berdasarkan sumbu kebersamaan ketangguhan

Oleh karenanya, dengan melihat nilai yang dianut, maka sketsa gagasan 08 dianggap sebagai nilai yang paling tepat. Hasil dari survey dapat dipetakan seperti yang tampak pada Gambar 8. Pada pemetaan hasil survey dalam bentuk grafik diatas terlihat bahwa desain 08 mampu mewakili kompromi antara sifat dari desain kendaran yang memiliki fungsi sebagai kendaraan yang harus memiliki karakter tangguh dengan kesesuaian nilai yang berlaku di masyarakat Sunda.

\section{Kesimpulan}

Penilaian yang dilakukan oleh para responden memperlihatkan kesesuaian dari penerapan sifat yang coba ditampilkan dari setiap gagasan. Upaya penafsiran dari gagasan yang diajukan sebagian besar memperlihatkan respon yang sama terhadap tafsiran sifat yang ada dibenak sebagian besar responden. Kesimpulan ini menghasilkan pijakan bagi konsep visual yang akan digunakan sebagai landasan bagi perancangan desain yang memiliki kesesuaian dengan nilai yang dianut oleh masyarakat tertentu. Penelitian baru sampai pada tahap bagaimana sebuah nilai yang diperoleh dari tafsiran pepatah dapat dijadikan konsep visual sebuah perancangan, dengan asumsi bahwa penafsiran yang dilakukan adalah benar.

Penelitian ini memerlukan penelitian lanjutan untuk membuktikan apakah konsep visual yang ditawarkan benar-benar dapat diterima oleh masyarakat pengguna produk yang dirancang. Permasalahan ini membutuhkan penelitian lebih lanjut dalam bentuk prototype dengan skala $1: 1$, sehingga distorsi dari sifat yang disampaikan tidak terjadi sebagaimana penafsiran yang dilakukan terhadap sebuah gambar 2 dimensi.

\section{Daftar pustaka}

Akihary, W. (2011). Nilai Budaya Dalam Peribahasa Kei Tentang Pengelolaan Wilayah Pesisir. Lingua: Jurnal Ilmu Bahasa dan Sastra Vol 6(2) 141-142

Bloch, P. H. (1995 ). Seeking the Ideal Form: Product Design and Consumer Response . Journal of Marketing Vol 59

Crilly, N., Moultrie, J., \& Clarkson, P. J. (2004). Seeing things: consumer response to the visual domain in product design. Design Studies, 25(6)

Desmet, P. M. (2003). A Multilayered Model of Product Emotions . The Design Journal Vol 6 No 2 , 4-13.

Djava, A. (2017, FEBRUARI 23 ). Inilah Filosofi Hidup Orang Sunda Yang Perlu Anda Ketahui. Retrieved from News Warta Publik: https://newswartapublik.wordpress.com/2017/02/23/inilahfilosofi-hidup-orang-Sunda-yang-perlu-anda-ketahui/

Faquha. (2016, August 14). Falsafah dan pepatah Urang Sunda Asli (USA). Retrieved from http://www.faquha.com: http://www.faquha.com/2016/08/falsafah-dan-pepatah-urangSunda-asli.html

Fauzi, D. R. (2017, Februari 28). Menggali Budaya Politik dari Falsafah Sunda " Silih Asah, Silih Asih, Silih Asuh". Retrieved from kompasiana: https://www.kompasiana.com/dadanrizwan/menggali-budayapolitik-dari-falsafah-Sunda-silih-asah-silih-asih-silihasuh_58b5873f29b0bd4312704acf

Fiske, J. (1990). Introduction to Communication Studies. London: Routledge

Hout, M. v. (2006, Agustus 6). Getting Emotional With... Hartmut Esslinger. Retrieved from Design and Emotion: http://www.design-emotion.com/2006/08/15/gettingemotional-with-hartmut-esslinger/

Jourdan, C., \& Tuite, K. (2006). Language, Culture, and Society. New York: Cambridge University Press.

Masri, A. (2010). Strategi Visual: bermain dengan formalistik dan semiotik untuk menghasilkan kualitas visual dalam desain. Yogyakarta: Jalasutra

Oktavianus. (2013). Semangat Profesionalisme Dalam Peribahasa Minangkabau. Jurnal Pendidikan Bahasa dan Sastra Vol 13, No 2, 215-224

Santosa, A. (2009, September 1). Nilai dan Norma Sosial. Retrieved from Agsa's Weblog: https://agsasman3yk.wordpress.com/2009/09/01/nilai-dannorma-sosial/

Sibarani, R. (2004). Antropolinguistik: Antropologi Linguistik dan Linguistik Antropologi. Medan: Penerbit Poda

Vihma, S. (1995). Products as Representations: A Semiotic and Aesthetic Study of Design Products . Helsinki: University of Art and Design, Finland

Zoest, A. V. (1993). Semiotika: Tentang Tanda, Cara Kerjanya dan Apa Yang Kita Lakukan Dengannya. Jakarta: Yayasan Sumber Agung 